\title{
The Ability of a Soil Temperature Gradient-Based Methodology to Detect Leaks from Pipelines in Buried District Heating Channels
}

\author{
Matjaž Perpar * and Zlatko Rek (1) \\ Laboratory for Fluid Dynamics and Thermodynamics, Faculty of Mechanical Engineering, \\ University of Ljubljana, 1000 Ljubljana, Slovenia; zlatko.rek@fs.uni-lj.si \\ * Correspondence: matjaz.perpar@fs.uni-lj.si
}

check for updates

Citation: Perpar, M.; Rek, Z. The Ability of a Soil Temperature Gradient-Based Methodology to Detect Leaks from Pipelines in Buried District Heating Channels. Energies 2021, 14, 5712. https://doi.org/ $10.3390 /$ en14185712

Academic Editor: Antonio Rosato

Received: 4 August 2021

Accepted: 6 September 2021

Published: 10 September 2021

Publisher's Note: MDPI stays neutral with regard to jurisdictional claims in published maps and institutional affiliations.

Copyright: (c) 2021 by the authors. Licensee MDPI, Basel, Switzerland. This article is an open access article distributed under the terms and conditions of the Creative Commons Attribution (CC BY) license (https:// creativecommons.org/licenses/by/ $4.0 /)$.

\begin{abstract}
We carried out several numerical experiments to analyze how different boundary conditions affect the ability to detect small pipeline leaks. Our method is based on determining the soil temperature gradient above a buried district heating channel. The equivalent thermal conductivity of a wet insulation $\left(\lambda_{\text {eq }}\right)$ value of $0.5 \mathrm{~W} /(\mathrm{m} \cdot \mathrm{K})$ was used to mimic a small water leakage. To evaluate the heat loss through the channel cross section, the heat conduction model was used for the pipe insulation, the concrete, and the soil, while the convection model was considered within the channel. The following effects were used to simulate different operating conditions: heat convection at the soil surface, leakage only from the supply or return pipe, soil height above the channel, soil thermal conductivity, and pipe diameter. With the exception of leakage only from the return pipe and low soil thermal conductivity $0.4 \mathrm{~W} /(\mathrm{m} \cdot \mathrm{K})$, the results showed a doubling of the soil temperature gradient when compared with the no-leakage case. This fact undoubtedly confirms the potential of the method, which is particularly suitable for leak detection in old pipelines that have priority for renovation. A key added value of this research is that the soil temperature gradient-based leak detection technique was found useful in most foreseeable DH operating situations.
\end{abstract}

Keywords: district heating network; heat losses; numerical experiment; soil temperature gradient; water leak; detection method robustness

\section{Introduction}

The purpose of this article is to examine the possibility of detecting small water leaks from district heating $(\mathrm{DH})$ pipes in buried concrete channels under various operating conditions. The research relates to the district heating system of Ljubljana, where about $130 \mathrm{~km}$ of such pipelines, most of which are over 50 years old, are installed. In the period from 2005 to 2009 heat loss in the network pipeline was $16.1 \%$ of the total heat input. This value is similar to $17 \%$ as reported in [1]. We deal with the insulation condition, which is still considered a key parameter in methodologies for evaluating heat losses in $\mathrm{DH}$ networks, e.g., [2]. Minimizing losses in the DH network is also an important activity to meet the requirements of the fourth-generation district heating (4GDH) concept [3]. Within this concept, leakage detection and elimination has been highlighted as an important measure [4]. In view of the above, it is necessary to highlight the renovation of old pipelines where leakage is not unusual. Successful detection of small leaks and their remediation certainly helps to achieve the target value about $4 \%$ of heat losses in the network pipeline of modern district heating systems, achieved above all by the reduction of supply and return temperature [5]. According to the $4 \mathrm{GDH}$ concept, a reduction in heat demand and heat density leads to higher relative heat losses in the heating network [6,7]. These can be reduced by reducing the supply temperature, for which well-maintained piping is a necessity. In this context, upgrading the system by considering the fifth-generation district heating and cooling (5GDHC) concept would be very advantageous [8]. Regardless of the 
concept, this renovation is associated with high investment costs [9] but is important not only to minimize heat loss but also to reduce additional pressure drops in the network.

A number of studies using the numerical simulation of the temperature field have been carried out to identify pipeline heat loss in a buried channel with dry [10-12] or wet pipeline insulation $[13,14]$. In this study, we used a numerical procedure that was presented in detail and validated by an experiment in our previous work [15], a leak detection methodology based on the determination of the soil temperature gradient above the channel was found to be successful. The research motivation of the present study was to verify the robustness of the method. Ten simulation cases were performed to determine how different boundary conditions influence the soil temperature gradient in the case of a pipeline leak. This was carried out with $\lambda_{\mathrm{eq}}=0.5 \mathrm{~W} /(\mathrm{m} \cdot \mathrm{K})$ to imitate the thermal conductivity of the wet insulation [15]. The variation of the operating parameters, including the heat transfer coefficient at ground level, leakage only from the supply pipe, soil height above the channel, soil thermal conductivity, and the diameter of the pipeline, showed a doubling of the soil temperature gradient in the case of wet insulation. A smaller gradient increase was found in two cases: (1) a 40\% gradient increase due to return pipe leak only and (2) an $80 \%$ gradient increase due to low soil thermal conductivity, $\lambda_{\mathrm{s}}=0.4 \mathrm{~W} /(\mathrm{m} \cdot \mathrm{K})$.

The key contribution of this work was to confirm that the detection of small water leaks from pipes in buried district heating channels is possible for most foreseeable $\mathrm{DH}$ operating situations. Leak detection requires suitable experimental implementation to control the heat loss through the soil $[16,17]$. For this purpose, only temperature sensors are required (for example, the use of a digital pyrometer) [18]. The presented methodology can also serve as a supplement to infrared thermography, one of the most promising leakage detection techniques for district heating networks [19].

The article is written as follows. In Section 2, the importance of detecting and dealing with small leaks in DH networks is discussed in more detail. The organization of numerical simulations is given in Section 3. Firstly, governing equations, computational domain with discretization, material properties, boundary conditions, and numerical solutions for computations are presented. Secondly, grounds for the selection of simulation cases are stated. Results are collected and discussed in Section 4 including the reliability of leakage detection. The conclusions are summarized in Section 5.

\section{Significance of Small Leakage Detection in DH Networks}

Based on our measurements [20], the equivalent thermal conductivity of the insulation along the pipe was determined to be within 0.8 and $1 \mathrm{~W} /(\mathrm{m} \cdot \mathrm{K})$ at a leak volume flow rate of $500 \mathrm{~kg} / \mathrm{h}$. Based on our previous experience [15], $\lambda_{\mathrm{eq}}=0.5 \mathrm{~W} /(\mathrm{m} \cdot \mathrm{K})$ was used in the numerical experiments presented in this paper to imitate a leakage below $500 \mathrm{~kg} / \mathrm{h}$, which undoubtedly can be defined as a small leak. The selected $\lambda_{\text {eq }}$ value can be considered appropriate to obtain a leakage detection limit that is as low as possible. Since we consider pipelines that are mostly older than 50 years, such leaks are an inevitable fact. However, the eligibility for renovation is always in question as it is associated with relatively high costs. As discussed in [21], there are four parameters that are not in favor of the current investment in larger district heating systems: (1) reduced heat demand due to building renovation, leading to the relative increase in the pipeline heat loss, (2) high cost of DH transmission and the distribution network, (3) different business strategies between facility operators and energy distributors, and (4) the use of fossil fuels for heat generation. Let us present the problems of the second parameter in more detail: (a) the calculation of the additional heat loss due to leakage, including the loss due to water runoff into the surroundings, and (b) the determination of the distributed heat to obtain a rough estimate of the renovation cost.

(a) The average nominal diameter $(\mathrm{DN})$ of the channel pipe in our case was determined to be $200 \mathrm{~mm}$ [10]. For our basic numerical computation [15] (DN 200, soil thermal conductivity $\lambda_{\mathrm{s}}=0.8 \mathrm{~W} /(\mathrm{m} \cdot \mathrm{K})$, soil height $\left.H_{\mathrm{s}}=0.9 \mathrm{~m}\right)$, the linear heat loss per meter of pipe was calculated to be $125.9 \mathrm{~W} / \mathrm{m}(60.8 \mathrm{~W} / \mathrm{m}$ for dry insulation and an additional 
$65.1 \mathrm{~W} / \mathrm{m}$ due to leakage). Additionally, it was estimated that $1.5 \%$ of the total heat input (1231 GWh in 2009) was lost due to water runoff into the surroundings [10]. Distributed over $130 \mathrm{~km}$ of pipeline in channels, the runoff corresponds to $0.142 \mathrm{MWh} / \mathrm{m}$ of heat loss in one year. Recalculated as the linear heat loss, this is $16.2 \mathrm{~W} / \mathrm{m}$. The sum of all contributions, $142.1 \mathrm{~W} / \mathrm{m}$, represents a 2.34 -fold increase of the heat loss compared to that for dry insulation. Furthermore, these heat radiation effects (emissivity $\varepsilon=0.93$ for the cardboard cover roof of the pipe insulation) can cause a roughly $20 \%$ increase of the soil temperature gradient [15]. The insulation is no longer functional in any case and thus needs to be replaced. However, since small leaks are difficult to trace, DH companies usually solve the problem by gradually replacing old pipelines, as is the case in Ljubljana [22].

(b) Following the procedure in [21], the distributed heat flux $Q$ is calculated by the equation $Q=\rho_{\mathrm{w}} v_{\mathrm{w}} A c_{\mathrm{p}, \mathrm{w}} \Delta \theta_{\mathrm{w}}$, where $\rho_{\mathrm{w}}$ and $v_{\mathrm{w}}$ are the density and average velocity of water, respectively, $A$ is the internal cross section of the pipe, $c_{\mathrm{p}, \mathrm{w}}$ is the specific heat of water, and $\Delta \theta_{\mathrm{w}}$ is the difference between supply and return temperature. For the case of a DN 200 pipe (for the average water velocity of $0.9 \mathrm{~m} / \mathrm{s}$ [23]), the distributed heat flux was calculated to be $4.75 \mathrm{MW}$. The pipes in the concrete channels are usually replaced with preinsulated pipes. The price of a single pipe system can be considered 640 EUR per meter [24]. Although this price means a high investment return time, there are additional advantages: (i) installing piping of the higher insulation class ( $22 \%$ reduction of the distribution heat loss [25]), (ii) a reduction of the chemical water treatment costs, and (iii) a reduction of water pumping costs. The leak elimination helps to achieve the required pressure at the DH end points.

\section{Numerical Simulations}

\subsection{Governing Equations}

The modeling of heat transfer in a heating network numerically represents a 3D problem (see e.g., [26]). Since in our case we considered a part of a straight channel segment, few meters long in the vicinity of a leak, we assumed that flow and temperature of water in the pipeline are constant. Due to this, we simplified the problem and treated it as a $2 \mathrm{D}$ example.

Two-dimensional transient-steady-state-combined (TSC) simulations [15] represent a basis for the numerical model used to evaluate the heat transfer across the channel cross section. The natural convection in the channel and the heat transfer through the solids is governed by the following [27]:

- Continuity equation:

$$
\partial \rho / \partial t+\nabla \cdot(\rho \boldsymbol{u})=0
$$

- Momentum equation:

$$
\partial(\rho \boldsymbol{u}) / \partial t+\nabla \cdot(\rho \boldsymbol{u} \boldsymbol{u})=-\nabla p+\nabla \cdot\left[\mu\left(\nabla \boldsymbol{u}+\nabla \boldsymbol{u}^{T}-2 / 3 \nabla \cdot \boldsymbol{u} I\right)\right]+\rho \boldsymbol{g} ;
$$

- Energy equation:

$$
\partial(\rho E) / \partial t+\nabla \cdot[u(\rho E+p)]=\nabla \cdot(\lambda \nabla T), E=c_{p} T-p / \rho+1 / 2 u^{2} ;
$$

- Equation of state:

$$
p=\rho r T,
$$

where $u$ is a velocity vector, $\rho$ is the density, $p$ is the pressure, $g$ is the acceleration due to gravity, $\mu$ is the dynamic viscosity, $I$ is the identity matrix, $T$ is the temperature, $\lambda$ is the thermal conductivity, $c_{p}$ is the specific heat, and $r$ is the specific gas constant. 


\subsection{Computational Domain and Discretization}

For the DH system in Ljubljana, the average nominal diameter (DN) of the pipeline in the channel was determined to be $200 \mathrm{~mm}$ [10]. Consequently, the configuration of the DN 200 channel was selected as the basic configuration.

Figure 1 shows a computational domain consisting of three solid subdomains (soil, concrete, insulation) and one fluid subdomain (air). The distance between the soil surface and the top of the concrete channel was $0.65 \mathrm{~m}$ or $0.9 \mathrm{~m}$. The extension of the soil subdomain was $2 \mathrm{~m}$ to the left and right of the concrete channel sides. The same soil subdomain extension was used at the channel's bottom side. The supply pipe was insulated with $100 \mathrm{~mm}$ of glass wool insulation, while the return pipe's insulation thickness was $50 \mathrm{~mm}$.

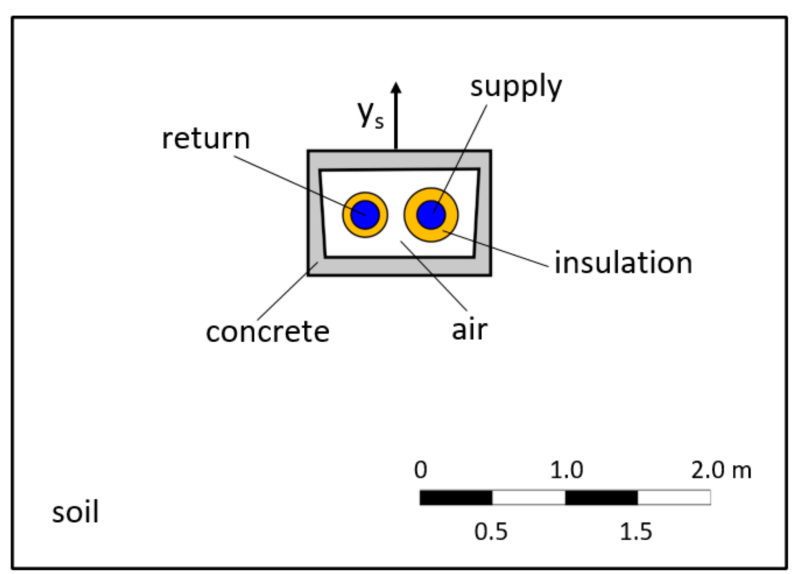

Figure 1. Domain geometry, where $y_{s}$ stands for the soil depth.

The whole computational domain was discretized with 93,793 quadrilateral cells. As in [16], a fine grid was used. In the insulation subdomain, the cell size was $5 \mathrm{~mm}$, while for all other subdomains, the cell size was $50 \mathrm{~mm}$. The mesh quality parameters of the computational grid were as follows:

- Minimum cell orthogonal quality-0.815;

- Maximum cell ortho skew-0.185;

- Maximum cell aspect ratio-2.671.

The values of the mesh quality parameters mean that the computational grid was good and would not be the cause of problems in the numerical solution.

\subsection{Material Properties and Boundary Conditions}

Air was used as the working fluid to enable convective heat transfer between the pipe insulation and the concrete wall of the channel. The physical properties of the materials used in the numerical simulation are:

- Air-density $\rho$ from the equation of state for an ideal gas, specific heat $c_{\mathrm{p}}=1006 \mathrm{~J} /(\mathrm{kg} \cdot \mathrm{K})$, thermal conductivity $\lambda=0.024 \mathrm{~W} /(\mathrm{m} \cdot \mathrm{K})$, dynamic viscosity

$\mu=1.789 \times 10^{-5} \mathrm{~kg} /(\mathrm{m} \cdot \mathrm{s})$, specific gas constant $r=287.058 \mathrm{~J} /(\mathrm{kg} \cdot \mathrm{K})$;

- Steel- $\rho=8030 \mathrm{~kg} / \mathrm{m}^{3}, c_{\mathrm{p}}=502.5 \mathrm{~J} /(\mathrm{kg} \cdot \mathrm{K}), \lambda=16.27 \mathrm{~W} /(\mathrm{m} \cdot \mathrm{K})$;

- Concrete- $\rho=2000 \mathrm{~kg} / \mathrm{m}^{3}, c_{\mathrm{p}}=879 \mathrm{~J} /(\mathrm{kg} \cdot \mathrm{K}), \lambda=1.14 \mathrm{~W} /(\mathrm{m} \cdot \mathrm{K})$;

- Soil- $\rho=1800 \mathrm{~kg} / \mathrm{m}^{3}, c_{\mathrm{p}}=880 \mathrm{~J} /(\mathrm{kg} \cdot \mathrm{K}), \lambda=0.8 \mathrm{~W} /(\mathrm{m} \cdot \mathrm{K})$;

- Insulation- $\rho=20 \mathrm{~kg} / \mathrm{m}^{3}, c_{\mathrm{p}}=840 \mathrm{~J} /(\mathrm{kg} \cdot \mathrm{K}), \lambda=0.047 \mathrm{~W} /(\mathrm{m} \cdot \mathrm{K})$ for no-leak case and $\lambda=0.5 \mathrm{~W} /(\mathrm{m} \cdot \mathrm{K})$ for leak case.

The mean value of the heat losses simulated per day for the entire year of 2009 corresponded to heat losses on day 304, 31 October [10], which is why the boundary conditions for this day were used in all simulations of the present work. These included the following temperatures: 
- $\quad 3.7^{\circ} \mathrm{C}$ for the soil surface, assumed to be equal to the temperature of surrounding air [16]);

- $10{ }^{\circ} \mathrm{C}$ for the soil temperature at the bottom boundary, equal to the undisturbed ground temperature;

- $100{ }^{\circ} \mathrm{C}$ for water temperature in the supply pipeline;

- $60^{\circ} \mathrm{C}$ for water temperature in the return pipeline.

Simulations also considered the symmetry on the left and right boundaries and the conjugate heat transfer through the solid domains: soil, concrete, and pipe insulation.

As an initial condition for the temperature field in the transient simulation, the result of the calculation of the steady heat conduction for the stated temperature boundary conditions and the resting air was used.

\subsection{Computations}

The numerical simulations were performed with the ANSYS Fluent 2D solver. The transient calculation was conducted by using a first-order implicit scheme. The assumption regarding the laminar flow regime was based on the fact that the Rayleigh number was between $5.9 \times 10^{5}$ and $1.4 \times 10^{6}$. The SIMPLE (Semi-Implicit Method for Pressure-Linked Equations) solver option for the coupling of velocity and pressure fields was used. Spatial discretization schemes were the following:

- Gradient operator-Green-Gauss-cell-based;

- $\quad$ Pressure-PRESTO (Pressure Staggering Option);

- Density, momentum and energy-second-order upwind.

The relaxation factors were as follows:

- 0.3 for pressure;

- 0.7 for momentum;

- 1.0 for density and energy.

The maximum residuals (convergence criteria) for the iterative procedure were limited to $10^{-12}$ for energy equation and $10^{-4}$ for all other equations. The allowed maximum number of iterations within each time step was set to 20 . Since the numerical model had already been experimentally checked [15], it was possible to analyze the robustness of the leakage detection method utilizing the numerical experiments.

\subsection{Selection of Simulation Cases}

Since the consideration of the convection numerical model within the channel already caused about a twofold increase in the soil temperature gradient, the radiation model was not considered in the simulations discussed in this paper. The soil temperature fields above the channel for the basic numerical computation, here called Simulation Case 1, are shown in Figure 2a. The reduced soil temperature equidistance indicates an increase of the temperature gradient in the leakage case (equivalent thermal conductivity of the insulation $\left.\lambda_{\mathrm{eq}}=0.5 \mathrm{~W} /(\mathrm{m} \cdot \mathrm{K})\right)$. The soil temperature gradient ratio (STGR)-a quotient between the leak and no-leak gradient-is shown in Figure $2 \mathrm{~b}$ as a function of $\lambda_{\text {eq. }}$. The smoothed line (Microsoft Excel) indicates a strong STGR reduction between $\lambda_{\text {eq }}=0.5 \mathrm{~W} /(\mathrm{m} \cdot \mathrm{K})$ and $\lambda_{\text {eq }}=1.0 \mathrm{~W} /(\mathrm{m} \cdot \mathrm{K})$. It can be concluded that the more than doubled soil temperature gradient at $\lambda_{\text {eq }}=0.5 \mathrm{~W} /(\mathrm{m} \cdot \mathrm{K})$ certainly confirms the choice of this $\lambda_{\text {eq }}$ value to characterize the leak in all numerical experiments discussed in this work.

To cover most of the variables that occurred during the normal operation of the $\mathrm{DH}$ network, nine further simulation cases were carried out. The variables were heat convection at the soil surface, leakage only from the supply or return pipe, soil height above the channel, soil thermal conductivity, and pipe diameter. The different compared operating conditions are shown in Table 1. Each case included no-leak and leak computations. 


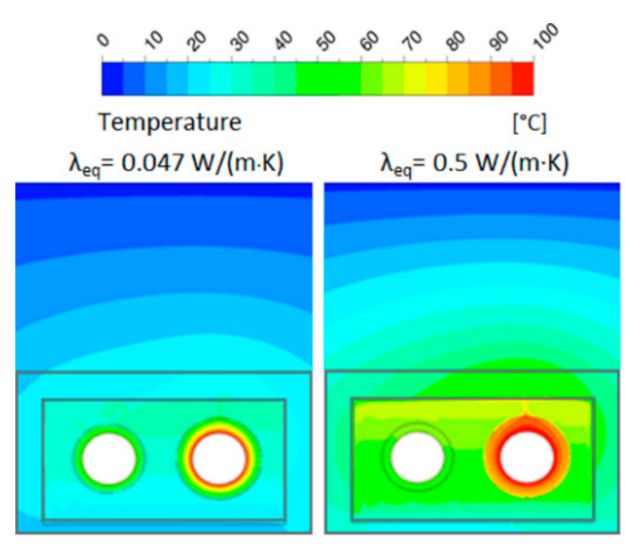

(a)

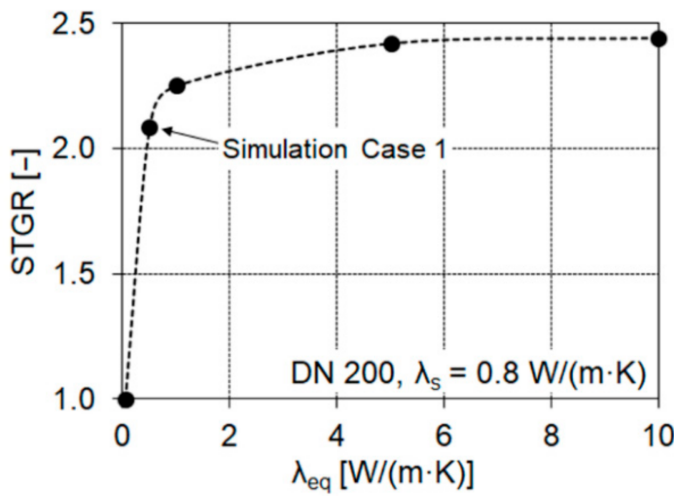

(b)

Figure 2. (a) Computed soil temperature fields above the channel for Simulation Case 1 and (b) soil temperature gradient ratio for different equivalent thermal conductivities of the insulation.

Table 1. Operating conditions for the simulation cases.

\begin{tabular}{|c|c|c|c|c|c|c|c|c|c|c|}
\hline Simulation Case & 1 & 2 & 3 & 4 & 5 & 6 & 7 & 8 & 9 & 10 \\
\hline \multicolumn{11}{|l|}{ Variable } \\
\hline$h, \mathrm{~W} /\left(\mathrm{m}^{2} \cdot \mathrm{K}\right)$ & - & 11.3 & & - & - & - & - & - & - & - \\
\hline Supply leak only & - & - & Yes & - & - & - & - & - & - & - \\
\hline Return leak only & - & - & - & Yes & - & - & - & - & - & - \\
\hline$H_{\mathrm{s}}, \mathrm{m}$ & 0.9 & 0.9 & 0.9 & 0.9 & 0.65 & 0.9 & 0.65 & 0.65 & 0.9 & 0.9 \\
\hline$\lambda_{\mathrm{s}}, \mathrm{W} /(\mathrm{m} \cdot \mathrm{K})$ & 0.8 & 0.8 & 0.8 & 0.8 & 0.8 & 0.8 & 0.4 & 1.2 & 0.8 & 0.8 \\
\hline $\mathrm{DN}, \mathrm{mm}$ & 200 & 200 & 200 & 200 & 300 & 300 & 300 & 300 & 50 & 900 \\
\hline
\end{tabular}

$h$, heat transfer coefficient at the soil surface; $H_{\mathrm{s}}$. soil height; $\lambda_{\mathrm{s}}$, soil thermal conductivity; DN, nominal pipe diameter.

\section{Results and Discussion}

\subsection{Heat Convection at the Soil Surface}

In [28], a constant value of $h=14.6 \mathrm{~W} /\left(\mathrm{m}^{2} \cdot \mathrm{K}\right)$ was taken for the heat transfer coefficient at the soil surface, including convection and radiation. Furthermore, in $[11,13,14]$, a similar value of $15 \mathrm{~W} /\left(\mathrm{m}^{2} \cdot \mathrm{K}\right)$ was used for the heat transfer coefficient between the ground and surrounding air. In our previous work [16], the average temperature difference between the air and soil surface was measured in the period of the last three months of 2009 with $\Delta \theta$ $=2{ }^{\circ} \mathrm{C}$. The heat flux density through the soil above the DN 200 channel on the reference day (31 October 2009) was measured at $q_{\mathrm{s}}=22.5 \mathrm{~W} / \mathrm{m}^{2}$ [10]. From the equation

$$
q_{\mathrm{s}}=h \Delta \theta,
$$

a heat transfer coefficient at the soil surface of $h=11.3 \mathrm{~W} /\left(\mathrm{m}^{2} \cdot \mathrm{K}\right)$, not much lower than the values specified in $[11,13,14,28]$, was calculated. A comparison of the soil temperature profiles simulated for this case with the base case (no-leak and leak) is shown in Figure $3 a$. A soil temperature gradient was determined via the best linear fit of the temperature profile data. Practically no change of the soil temperature gradient was found if the heat transfer at the soil surface was taken into account. This fact confirms that the soil surface temperature is a sufficient boundary condition [16]. However, as for the base case, more than a twofold increase of the soil temperature gradient was obtained.

It should also be emphasized that the difference in soil surface temperature was only $1.4{ }^{\circ} \mathrm{C}$ (see Figure 3a) when comparing the no-leak and leak cases with $h=11.3 \mathrm{~W} /\left(\mathrm{m}^{2} \cdot \mathrm{K}\right)$. In this case, utilizing the infrared thermography, it would be very difficult to attribute such a small temperature difference to a leak due to the measurement uncertainty caused by the different ground type (grass, asphalt, concrete). Here, the discussed methodology can certainly be helpful. Heat transfer at the soil surface is also affected by the radiation, 
e.g., [29]. Since the soil surface temperature was a sufficient boundary condition, the ground radiation effect was disregarded. Consideration of this impact would also significantly increase the computation time.

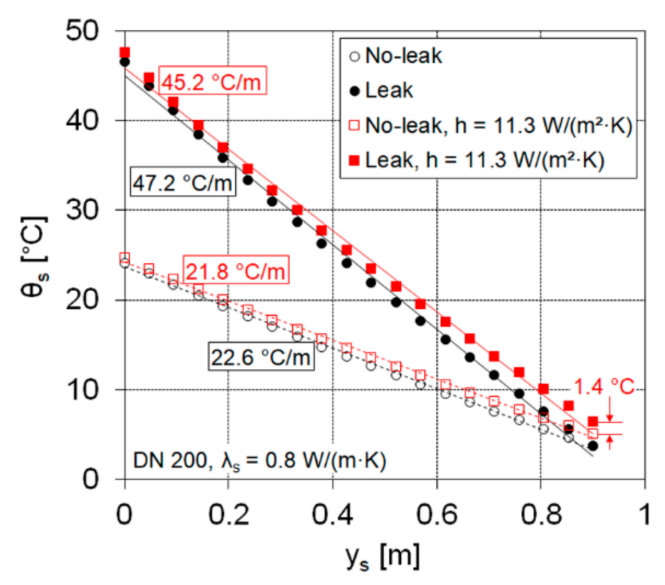

(a)

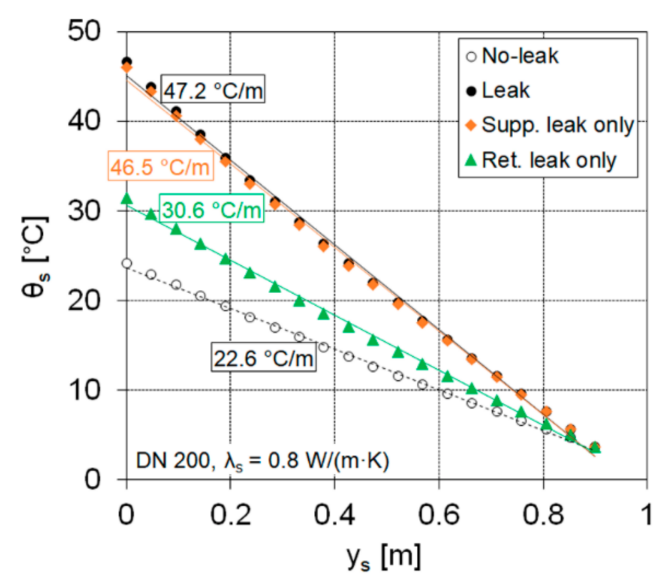

(b)

Figure 3. (a) Influence of the convection heat transfer at the soil surface (Simulation Case 2) and (b) influence of the leakage from supply and return pipe only (Simulation Cases 3 and 4).

\subsection{Supply or Return Pipe Leak Only}

Figure $3 b$ shows the computations for supply or return pipe leaks only. These scenarios are compared with the "Leak" one, representing a leakage from both pipes simultaneously. In the case of a supply pipe leak only, the soil temperature gradient was found not to be much lower than for both a supply and return leak $\left(46.5^{\circ} \mathrm{C} / \mathrm{m}\right.$ for the supply leak only vs. $47.2^{\circ} \mathrm{C} / \mathrm{m}$ for the both-pipe leak). It can be argued that for successful leak detection, supply pipe leakage is sufficient. In practice, the supply pipe leak only is more likely than the return pipe leak only due to the higher pressure in the supply pipe. Regardless, the return-pipe-leak case could represent the lower limit of detection since the soil temperature gradient increased by 1.4 times only, from $22.6^{\circ} \mathrm{C} / \mathrm{m}$ (no-leak) to $30.6{ }^{\circ} \mathrm{C} / \mathrm{m}$ (leak).

\subsection{Soil Height above the Channel}

The influence of the soil height was tested for the DN 300 channel. A comparison of the soil temperature profiles is shown in Figure 4a. It can be concluded that the soil height does not play a special role in the leak detection. The increase of the soil temperature gradient compared to the no-leak case was found to be similar for both soil heights, namely 2.2 times for $H_{\mathrm{s}}=0.65 \mathrm{~m}$ and 2.0 times for $H_{\mathrm{s}}=0.9 \mathrm{~m}$.

\subsection{Soil Thermal Conductivity}

For the period from 27 September to 5 November 2009, the mean value of the daily averaged soil thermal conductivity measurements $\left(\lambda_{\mathrm{s}}\right)$ was $0.826 \pm 0.085 \mathrm{~W} /(\mathrm{m} \cdot \mathrm{K})[10]$. These results are similar to those reported in [30], indicating a soil thermal conductivity in the range from $0.4 \mathrm{~W} /(\mathrm{m} \cdot \mathrm{K})$ to $1.7 \mathrm{~W} /(\mathrm{m} \cdot \mathrm{K})$ for sandy loam soil. This is certainly consistent with the fact that the city of Ljubljana is built on sand and gravel alluvium [31]. Based on our measurements, a value of $\lambda_{\mathrm{s}}$ rounded to $0.8 \mathrm{~W} /(\mathrm{m} \cdot \mathrm{K})$ was considered in the majority of numerical experiments (Simulation Cases 1-6, 9, 10). The influence of the soil thermal conductivity was tested via Simulation Cases 7 and 8 (see Figure $4 \mathrm{~b}$ ). The selected $\lambda_{\mathrm{s}}$ values $0.4 \mathrm{~W} /(\mathrm{m} \cdot \mathrm{K})$ and $1.2 \mathrm{~W} /(\mathrm{m} \cdot \mathrm{K})$ correspond to minimal and maximal local value measurements [16]. A lower soil temperature gradient increase was determined for $\lambda_{\mathrm{s}}=0.4 \mathrm{~W} /(\mathrm{m} \cdot \mathrm{K})$ than for $\lambda_{\mathrm{s}}=1.2 \mathrm{~W} /(\mathrm{m} \cdot \mathrm{K})$, at 1.8 and 2.3 times, respectively. The leak detection problem can arise from the fact that the no-leak gradient at $\lambda_{\mathrm{s}}=0.4 \mathrm{~W} /(\mathrm{m} \cdot \mathrm{K})$ is similar to the leak gradient at $\lambda_{\mathrm{s}}=1.2 \mathrm{~W} /(\mathrm{m} \cdot \mathrm{K}), 42.9^{\circ} \mathrm{C} / \mathrm{m}$ vs. $48.6^{\circ} \mathrm{C} / \mathrm{m}$. The issue can 
be further clarified with the comparison between the no-leak and leak soil temperature gradient $\left|\operatorname{grad} \theta_{\mathrm{S}}\right|$ as a function of the soil thermal conductivity (see Figure 5). The difference of the added constants in the logarithmic trend curves, $29.871{ }^{\circ} \mathrm{C} / \mathrm{m}$, shows the average leak vs. no-leak soil temperature gradient difference to be practically independent on $\lambda_{\mathrm{s}}$. This means that there is no problem with the leakage detection if $\lambda_{\mathrm{s}}$ is known; if not, a small difference in the soil temperature gradient between no-leak and leak cases $\left(5.7^{\circ} \mathrm{C} / \mathrm{m}\right.$, marked in Figure 5) may lead to an incorrect decision regarding the leak detection. When $\lambda_{\mathrm{s}}$, determined as proposed in [16], is $0.4 \mathrm{~W} /(\mathrm{m} \cdot \mathrm{K})$ or less, the possible leak should be checked by the channel monitoring as proposed in [15]. An additional possibility is to ascertain $\lambda_{\mathrm{s}}$ via the measured soil heat flux $q_{\mathrm{s}}$ and soil temperature, utilizing the equation

$$
q_{\mathrm{s}}=\lambda_{\mathrm{s}}\left|\operatorname{grad} \theta_{\mathrm{s}}\right|
$$

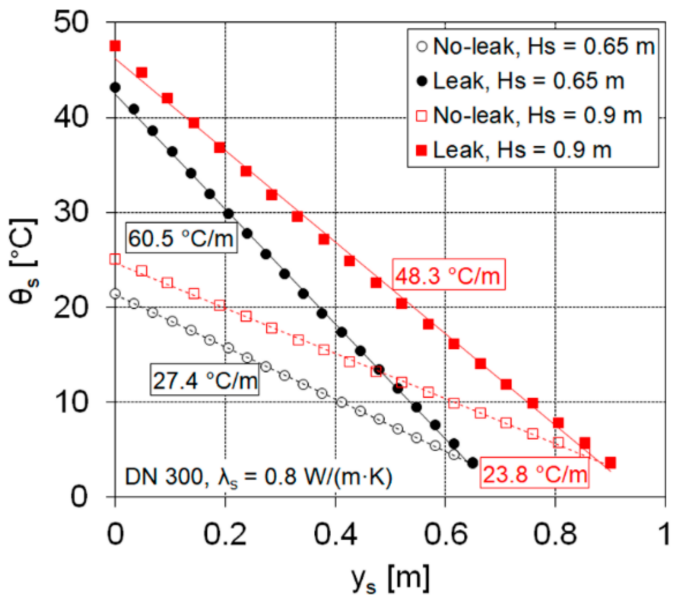

(a)

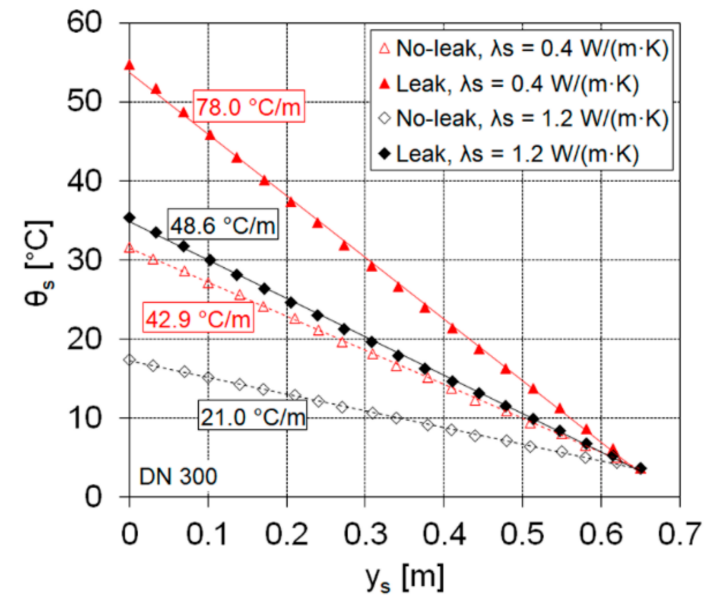

(b)

Figure 4. (a) Influence of the soil height above the channel $\left(H_{\mathrm{s}}=0.65 \mathrm{~m}\right.$ and $H_{\mathrm{s}}=0.9 \mathrm{~m}$ refer to Simulation Cases 5 and 6 , respectively) and $(\mathbf{b})$ influence of the soil thermal conductivity $\left(\lambda_{\mathrm{s}}=0.4 \mathrm{~W} /(\mathrm{m} \cdot \mathrm{K})\right.$ and $\lambda_{\mathrm{s}}=1.2 \mathrm{~W} /(\mathrm{m} \cdot \mathrm{K})$ refer to Simulation Cases 7 and 8 , respectively).

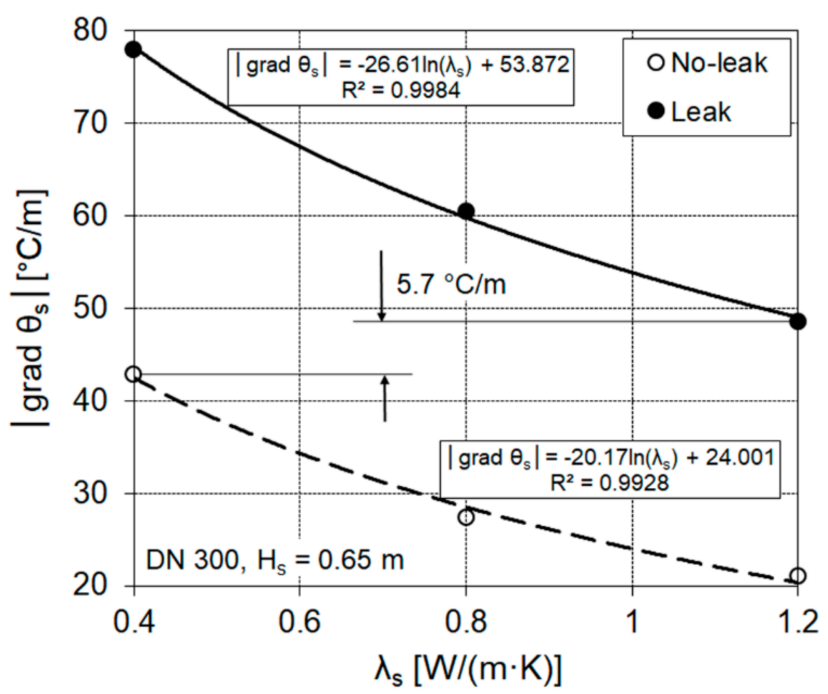

Figure 5. Comparison of no-leak and leak soil temperature gradients as a function of the soil thermal conductivity.

Although this method, applied in [10], can overestimate $\lambda_{\mathrm{s}}$ by up to $30 \%$, it can be helpful. 


\subsection{Channel Dimension}

To determine how the channel dimension influences the soil temperature gradient, simulations were carried out for the nominal pipe diameters of $50 \mathrm{~mm}, 200 \mathrm{~mm}, 300 \mathrm{~mm}$, and $900 \mathrm{~mm}$ (Figure 6). In all cases, the soil height above the channel was $0.9 \mathrm{~m}$. Regardless of the pipe diameter, more than a doubling of the soil temperature gradient was found in the case of leakage. For DN 50, the best fit of the soil temperature data $\left(R^{2}=0.999\right)$ is a quadratic function, but a linear fit with the soil temperature gradient of $38.6^{\circ} \mathrm{C} / \mathrm{m}$ is also acceptable $\left(R^{2}>0.98\right)$.

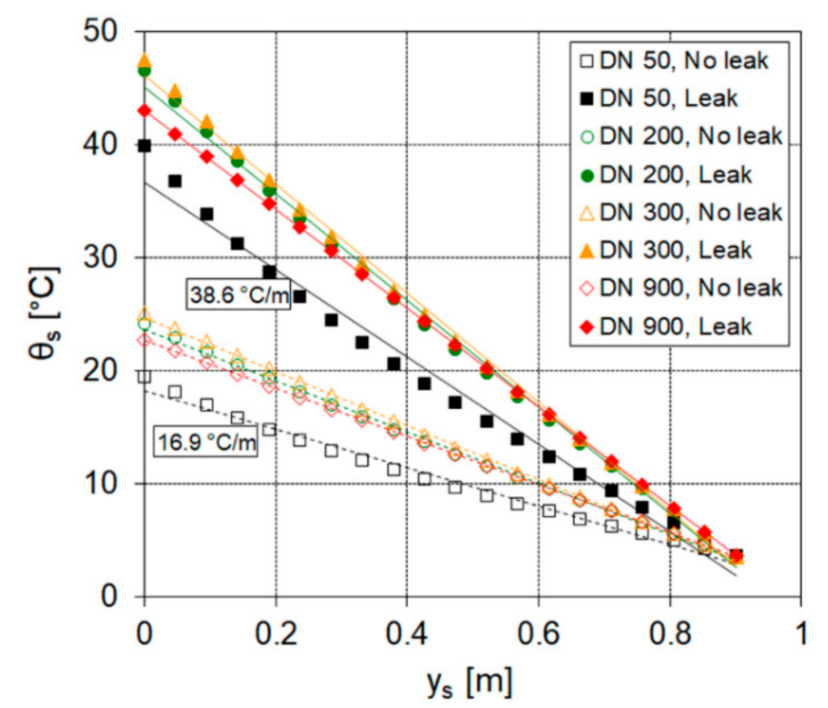

Figure 6. Influence of the channel dimension. DN 50, DN 200, DN 300, and DN 900 refer to Simulation Cases $9,1,6$, and 10 , respectively.

Temperature fields related to DN 50 and DN 900 for the no-leak and leak cases are shown in Figure 7. According to the chosen calculation domain, the simulation areas were $4.7 \mathrm{~m} \times 3.4 \mathrm{~m}$ for DN 50 and $7.39 \times 4.96 \mathrm{~m}$ for DN 900 .

Although the patterns of isotherms for DN 50 and DN 900 are different, the reduced soil temperature equidistance for the leak cases proves that the presented method can be successfully utilized.

\subsection{Reliability of Leakage Detection}

The reliability of the leakage detection is shown in Figure 8, where the soil temperature gradient ratios (STGRs) for the considered simulation cases are compared.

Let us emphasize that in $[11,13]$, a more than twofold increase in the soil temperature gradient above the channel was exhibited in the case of heat loss from the pipeline with the wet insulation due to the flooded concrete channel. Based on this fact, a doubling of the soil temperature gradient was taken as a lower limit for reliable leak detection.

STGR values, rounded to one decimal point, are displayed in ascending order (Figure 8). The minimum value (1.4) refers to Simulation Case 4 (return leak only). A somewhat higher STGR (1.8) was found for Simulation Case (low soil thermal conductivity $(0.4 \mathrm{~W} /(\mathrm{m} \cdot \mathrm{K})$ ). All other simulation examples met the desired condition of doubling the soil temperature gradient. 


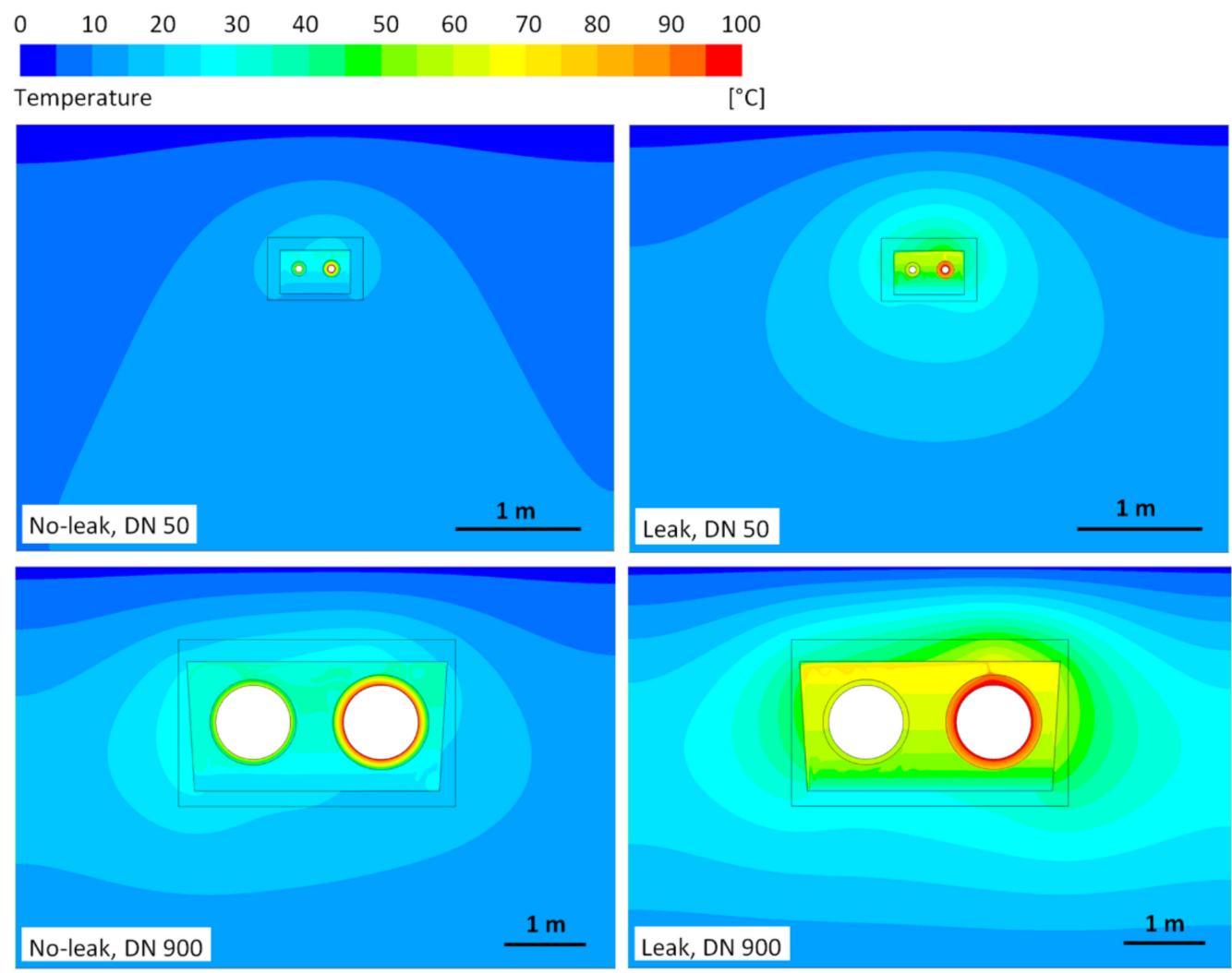

Figure 7. Simulated temperature fields for channels with nominal pipe diameters DN 50 and DN 900; no-leak and leak cases.

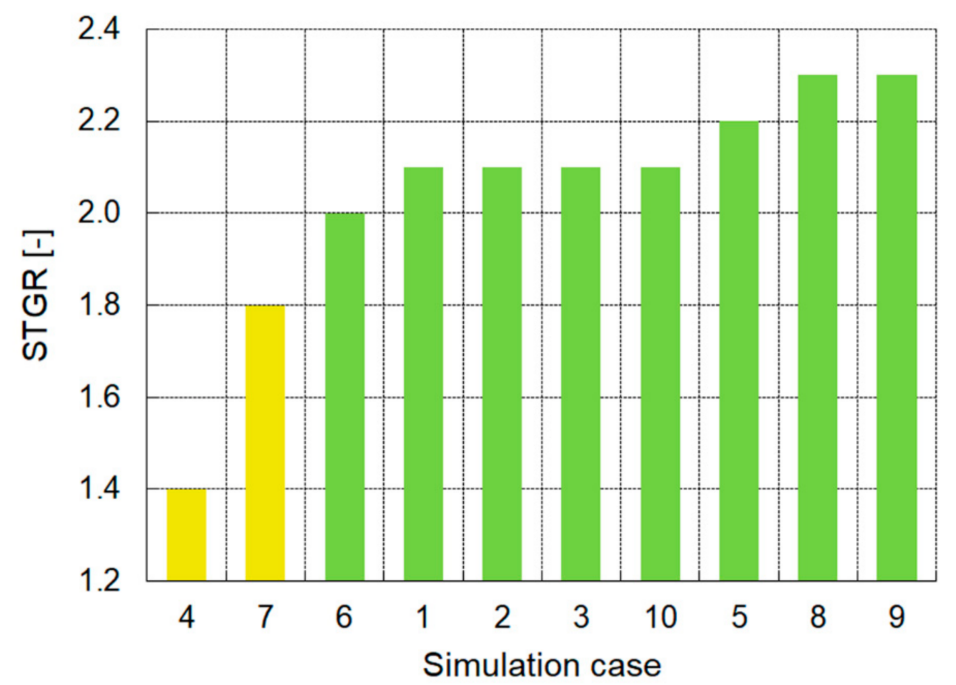

Figure 8. Comparison of the soil temperature gradient ratios (STGRs) for the considered simulation cases.

\section{Conclusions}

Different numerical experiments were carried out to analyze the influence of a variety of boundary conditions on the ability of a pipeline leak detection method based on the determination of the soil temperature gradient above a buried district heating channel. The methodology was checked by comparison of simulation and experimental field data [15]. Based on this previous study, the equivalent thermal conductivity of wet insulation $\left(\lambda_{\text {eq }}\right)$ value of $0.5 \mathrm{~W} /(\mathrm{m} \cdot \mathrm{K})$ was used to mimic a small water leakage into the pipe insulation. The heat loss through the channel cross section was evaluated using the heat conduction model for the pipe insulation, concrete, and soil, while inside the channel the convection model 
was used. To imitate different operating conditions, the following effects or variables were used in the simulations: heat convection at the soil surface, leakage only from the supply or return pipe, soil height above the channel, soil thermal conductivity, and pipe diameter. The results showed that, with the exception of leakage only at the return and low soil thermal conductivity $(0.4 \mathrm{~W} /(\mathrm{m} \cdot \mathrm{K})$, a doubling of the soil temperature gradient was achieved when compared to the no-leakage case. This fact undoubtedly confirms the potential of the method for detecting small water leaks from the pipelines in buried channels in most foreseeable DH operating situations. The equipment needed are temperature sensors with data recording and control system (e.g., as in [16,17]). In addition to a reduction of heat loss, it is also important to reduce the additional pressure drops in the network. Our proposed method is a useful tool, especially for pipeline renovation planning.

Author Contributions: Conceptualization, M.P.; methodology, M.P. and Z.R.; software, Z.R.; validation, M.P. and Z.R.; formal analysis, M.P. and Z.R.; investigation, M.P.; resources, M.P. and Z.R.; data curation, M.P. and Z.R.; writing—original draft preparation, M.P.; writing—review and editing, M.P. and Z.R.; visualization, M.P. and Z.R.; project administration, M.P. All authors have read and agreed to the published version of the manuscript.

Funding: This research was funded by the Slovenian Research Agency under contract no. P2-0162 and by JP Energetika Ljubljana, d. o. o., under contract no. JPE-SCV-49/11.

Institutional Review Board Statement: Not applicable.

Informed Consent Statement: Not applicable.

Conflicts of Interest: The authors declare no conflict of interest. The funders had no role in the design of the study; in the collection, analyses, or interpretation of data; in the writing of the manuscript; or in the decision to publish the results.

\section{References}

1. Volkova, A.; Latõšov, E.; Lepiksaar, K.; Siirde, A. Planning of district heating regions in Estonia. Int. J. Sustain. Energy Plan. Manag. 2020, 27, 5-16. [CrossRef]

2. Chicherin, S.; Mašatin, V.; Siirde, A.; Volkova, A. Method for assessing heat loss in a district heating network with a focus on the state of insulation and actual demand for useful energy. Energies 2020, 13, 4505. [CrossRef]

3. Lund, H.; Østergaard, P.A.; Chang, M.; Werner, S.; Svendsen, S.; Sorknæs, P.; Thorsen, J.E.; Hvelplund, F.; Mortensen, B.O.G.; Mathiesen, B.V.; et al. The status of 4th generation district heating: Research and results. Energy 2018, 164, 147-159. [CrossRef]

4. Li, H.; Nord, N. Transition to the 4th generation district heating-Possibilities, bottlenecks, and challenges. Energy Procedia 2018, 149, 483-498. [CrossRef]

5. Zajacs, A.; Borodinecs, A. Assessment of development scenarios of district heating systems. Sustain. Cities Soc. 2019, 48, 101540. [CrossRef]

6. Schweiger, G.; Kuttin, F.; Posch, A. District heating systems: An analysis of strengths, weaknesses, opportunities, and threats of the 4GDH. Energies 2019, 12, 4748. [CrossRef]

7. Pakere, I.; Romagnoli, F.; Blumberga, D. Introduction of small-scale 4th generation district heating system. Methodology approach. Energy Procedia 2018, 149, 549-554. [CrossRef]

8. Buffa, S.; Cozzini, M.; D'Antoni, M.; Baratieri, M.; Fedrizzi, R. 5th generation district heating and cooling systems: A review of existing cases in Europe. Renew. Sustain. Energy Rev. 2019, 104, 504-522. [CrossRef]

9. Sarbu, I.; Mirza, M.; Crasmareanu, E. A review of modelling and optimisation techniques for district heating systems. Int. J. Energy Res. 2019, 43, 6572-6598. [CrossRef]

10. Žun, I.; Perpar, M.; Rek, Z.; Gregorc, J. Setting up of Heat Loss Physical Model for DH System in Ljubljana. Report EN10-R7; DH company: Ljubljana, Slovenia, 2010. (In Slovene)

11. Kuznetsov, G.V.; Polovnikov, V.Y. The conjugate problem of convective-conductive heat transfer for heat pipelines. J. Eng. Thermophys. 2011, 20, 217-224. [CrossRef]

12. Zwierzchowski, R.; Niemyjski, O. Simulation of heat losses of a distribution network with different technical structure and under different operating conditions for a district heating and cooling system. IOP Conf. Ser. Mater. Sci. Eng. 2019, 603, 032091. [CrossRef]

13. Polovnikov, V.Y.; Razumov, N.V. Application of a convective-conductive heat transfer model in the heat loss analysis of a heat pipeline under flooding conditions. EPJ Web Conf. 2016, 110, 1-5. [CrossRef]

14. Polovnikov, V.Y. Numerical Investigation of the Thermal Regime of Underground Channel Heat Pipelines Under Flooding Conditions with the Use of a Conductive-Convective Heat Transfer Model. J. Eng. Phys. Thermophys. 2018, 91, 471-476. [CrossRef] 
15. Perpar, M.; Rek, Z. Soil temperature gradient as a useful tool for small water leakage detection from district heating pipes in buried channels. Energy 2020, 201, 117684. [CrossRef]

16. Perpar, M.; Rek, Z.; Bajric, S.; Zun, I. Soil thermal conductivity prediction for district heating pre-insulated pipeline in operation. Energy 2012, 44, 197-210. [CrossRef]

17. Song, S.; Kim, J.; Detection, L. Advanced Monitoring Technology for District Heating Pipelines Using Fiber Optic Cable. In Proceedings of the 15th International Symposium on District Heating and Cooling, Seoul, Korea, 4-7 September 2016; pp. 1-4.

18. Zhuravska, I.; Lernatovych, D.; Burenko, O. Detection the places of the heat energy leak on the underground thermal pipelines using the computer system. Adv. Sci. Technol. Eng. Syst. 2019, 4, 1-9. [CrossRef]

19. Zhou, S.; O'Neill, Z.; O'Neill, C. A review of leakage detection methods for district heating networks. Appl. Therm. Eng. 2018, 137, 567-574. [CrossRef]

20. Perpar, M.; Lojevec, N.; Gregorc, J.; Rek, Z.; Bajrić, S.; Žun, I. Heat loss evaluation in wet insulation of district heating pipeline in Ljubljana. In Proceedings of the International Conference on District Energy, Portorose, Slovenia, 23-25 March 2014.

21. Sandvall, A.F.; Ahlgren, E.O.; Ekvall, T. Cost-efficiency of urban heating strategies-Modelling scale effects of low-energy building heat supply. Energy Strateg. Rev. 2017, 18, 212-223. [CrossRef]

22. Matičič, P.; Trunkelj, S. Ensuring high reliability of Energetika Ljubljana district heating systems. In Proceedings of the International Conference on District Energy, Portorose, Slovenia, 19-21 March 2017.

23. Žun, I.; Perpar, M.; Polutnik, E.; Rek, Z.; Pečar, M.; Bajrić, S. Setting up of heat loss physical model for DH system in Ljubljana. Report EN06-R3; DH company: Ljubljana, Slovenia, 2006. (In Slovene)

24. Danish Energy Agency. Technology Catalogue for Transport of Energy \& $\mathrm{CO}_{2}$. 2021. Available online: https://ens.dk/en/ourservices / projections-and-models/technology-data/technology-data-energy-transport (accessed on 6 September 2021).

25. Best, I.; Orozaliev, J.; Vajen, K. Impact of Different Design Guidelines on the Total Distribution Costs of 4th Generation District Heating Networks. Energy Procedia 2018, 149, 151-160. [CrossRef]

26. Danielewicz, J.; Śniechowska, B.; Sayegh, M.A.; Fidorów, N.; Jouhara, H. Three-dimensional numerical model of heat losses from district heating network pre-insulated pipes buried in the ground. Energy 2016, 108, 172-184. [CrossRef]

27. $\quad$ ANSYS $^{\circledR}$ Academic Research CFD, Release 17.2. Available online: https:/ / www.ansys.com/ (accessed on 6 September 2021).

28. Bøhm, B. On transient heat losses from buried district heating pipes. Int. J. Energy Res. 2000, 24, 1311-1334. [CrossRef]

29. Bryś, K.; Bryś, T.; Ojrzyńska, H.; Sayegh, M.A.; Głogowski, A. Variability and role of long-wave radiation fluxes in the formation of net radiation and thermal features of grassy and bare soil active surfaces in Wrocław. Sci. Total Environ. 2020, 747, 141192. [CrossRef] [PubMed]

30. Ochsner, T.E.; Horton, R.; Ren, T. A New Perspective on Soil Thermal Properties. Soil Sci. Soc. Am. J. 2001, 65, 1641-1647. [CrossRef]

31. Soils of Slovenia with Soil Map 1:250,000. ISBN 9789279230639. Available online: http://soil.bf.uni-lj.si/projekti/pdf/atlas_ final_2015_reduced.pdf (accessed on 6 September 2021). 